\title{
O lenhador, uma releitura de Chapeuzinho vermelho
}

\author{
Rosângela Fachel de Medeiros*
}

\section{Resumo}

Esse artigo, na tradição dos estudos comparatistas interdisciplinares, analisa o filme $O$ lenhador como releitura e recriação do conto de fadas Chapeuzinho Vermelho, investigando os diálogos intertextuais que instaura com as duas versões mais famosas da estória infantil, a de Charles Perrault e a dos Irmãos Grimm. A investigação desses entrecruzamentos centra-se na questão da pedofilia que é tratada abertamente no filme e de maneira simbólica nos contos. Com esse intuito, é também abordado o romance Lolita, de Vladimir Nabokov, obra emblemática no tratamento do tema, que se configura como um ponto de confluência para as narrativas analisadas e traz para a discussão outra obra da literatura infantil, Alice no país das maravilhas, de Lewis Carroll.

\section{Palavras-chave}

Cinema. Literatura. Contos de fadas. Pedofilia.

Mesmo sendo a pedofilia ${ }^{1}$ um tema delicado a ser tratado, na história do cinema são muitos os filmes que abordam a questão seja através de insinuações ou do enfretamento direto e chocante. Recentemente, talvez como reflexo do maior desvelamento deste tipo de crime e do imenso repúdio social a tal comportamento, houve uma leva de filmes a respeito da questão. ${ }^{2}$ A maioria destes filmes centra a

* Doutora em Literatura Comparada pela UFRGS.

1 De acordo com sua etimologia, a palavra pedofilia (do grego paidophilia), nascida da combinação do substantivo paîs, paidos (criança) e do verbo phileo (amizade), significa amizade pelas crianças, gostar de crianças. Na Grécia antiga a pedofilia representava o amor homossexual e pedagógico de um homem maduro por um menino impúbere. Atualmente a palavra pedofilia designa o desejo sexual de um adulto em relação a crianças, sendo classificada pela psicologia como uma perversão sexual na ordem da parafilia.

2 Para enumerar alguns citamos: A sombra da dúvida (L'ombre du doute, 1993), As faces de Suzi Mitchell (The Terror Inside, 1996), Marcas da violência (Bastard out of Carolina, 1996), Abuso sexual (No Child of Mine, 1996), Sleepers: a vingança adormecida (Sleepers, 1996), Felicidade (Happiness, 1998), Festa de família (Dogme 1, Festen, 1998), Zona de conflito (The War Zone, 1999), Casamento à indiana (Monsoon Wedding, 2001), L.I.E. - Sem saída (L.I.E., 2001), Inocência marcada (Any and Isabelle, 2001), No limite do silêncio (The Unsaid, 2001), Sobre meninos e lobos (Mystic River - 2003), Má educação (La mala educación, 2004), O Lenhado (The Woodsman, 2004), Mistérios da carne (Mysterious Skin, 2004), assim como o controverso documentário Na captura dos Friedmans (Capturing the Friedmans) 2004, de Andrew Jarecki, e os recentes: Menina má. com (Hardy Candy, 2005), Acusado (Anklaget, 2005), Pecados íntimos (Litlle Girl, 2006) e Hounddog, 2007. 
narrativa nas vítimas da pedofilia e no resultado destes abusos em suas vidas, apresentando do pedófilo apenas o ato hediondo. Uma exceção notória é Felicidade (Happiness - 1998), de Tood Solondz, que apresenta o pedófilo como um dos protagonistas da trama. Contudo, O lenhador (The Woodsman - 2004), de Nicole Kassel, ${ }^{3}$ gerou desconforto em muitos espectadores, não apenas por apresentar o pedófilo/molestador - Walter, interpretado por Kevin Bacon, ${ }^{4}$ como protagonista, mas por retratá-lo de maneira humana, apresentando seus dilemas morais e seus conflitos familiares e amorosos, construindo um personagem multifacetado com nuances que vão além de seu desejo e de seu crime.

Conforme Kassel, ela queria apresentar o homem por trás do "monstro", abertamente inspirada pelo filme Os últimos passos de um homem (Dead Man Walking - 1995), de Tim Robins. ${ }^{5}$ Pois ela acredita que esse tipo de abordagem faz lembrar que tais "monstros" não vivem em um vácuo, mas convivem conosco em nossa sociedade, revelando assim a existência de um histórico de pequenas tragédias em suas vidas que culmina na tragédia maior do crime por eles cometido. (KASSEL, 2005)

O lenhador é um filme único na abordagem que dá à questão da pedofilia, tendo como tema central a pedofilia heterossexual em uma narrativa cujo protagonista e foco-narrativo é o pedófilo e não a vítima. Além disso, o pedófilo não é representando apenas como um vilão, mas também como vítima do desejo que o corrói. Tal abordagem faz de Walter um personagem capaz de gerar empatia nos espectadores e isso, se tratando de um pedófilo, é uma grande novidade.

Contudo, Lolita (1955), de Vladimir Nabokov, ${ }^{6}$ pode ser visto como precursor desse tipo de tratamento ao tema. O romance é narrado em primeira pessoa por um pedófilo confesso, Humbert Humbert, que desesperadamente apaixonado por Lolita, mas com extrema ironia, faz o leitor oscilar constantemente entre a simpatia e o repúdio, o perdão e a condenação. Conforme Eliane Moraes, a complexidade com que o romance elabora a imagem do perverso é notável:

Humbert Humbert é um personagem construído sobre paradoxos: se, de um lado, ele insiste em se definir como um pervertido, de outro, ele jamais corresponde à caricatura do tarado - ou, se preferirmos seu equivalente contemporâneo, do pedófilo -, sendo que tais estereótipos são colocados em xeque ao longo de todo o livro. (MORAES, 2007, p. 116)

${ }^{3}$ O filme é o primeiro longa-metragem da diretora Nicole Kassel que é também co-autora do roteiro conjuntamente com Steven Fechter, autor da peça de teatro homônima da qual o filme foi adaptado

${ }^{4}$ Coincidentemente Kevin Bacon já havia trabalhado em dois filmes que também tratam do tema da pedofilia: Sleepers e Sobre meninos e lobos.

${ }^{5}$ Os últimos passos de um homem conta a história do comovente relacionamento entre uma freira e um homem condenado à morte. Matthew Poncelet busca a ajuda da freira, Helen Prejean, para apelar de sua condenação. Ele é acusado de ter estuprado uma jovem, que se achava numa floresta com seu namorado, e de matar o casal em seguida. A princípio, ele nega a autoria dos crimes, culpando um amigo, Vitello, que se encontrava na ocasião bêbado e drogado. Contudo, após o pedido de clemência ser negado, ele confessa a autoria dos crimes à freira e se diz arrependido. A freira permanece ao lado de Matthew até o fim.

${ }^{6}$ Lolita foi adaptado para o cinema duas vezes, em 1962, por Stanley Kubrick e, em 1997, por Adrian Lyne. 
Tanto em $O$ lenhador quanto em Lolita são apresentadas as idiossincrasias existentes na vida dos pedófilos, não havendo uma representação estereotipada, o que força o espectador e/ou leitor a outra atitude distinta da simples condenação. Além disso, o fato de que em ambas as obras o pedófilo é o foco narrativo, narradorprotagonista, facilita a identificação entre o espectador e/ou leitor e o personagem.

Compreendemos logo que a grande controvérsia gerada pelo filme deve-se mais a sua abordagem do tema do que ao tema em si, levando o espectador a questionarse em muitos aspectos e trazendo-Ihe mais perguntas que respostas. Contudo, o intuído deste texto, sem se eximir a tais questionamentos, é o de analisar a forma como O lenhador dialoga com o conto infantil Chapeuzinho Vermelho do qual o título do filme foi retirado. Para tanto, apresentamos uma sinopse do filme que será seguida por uma breve análise da estória infantil e só posteriormente partiremos para a análise comparativa das narrativas.

\section{O Lenhador}

Após doze anos de prisão por molestar garotinhas, Walter recebe liberdade condicional e busca reconstruir sua vida na sociedade e resgatar o relacionamento com a irmã e a sobrinha enquanto luta contra seus impulsos pedófilos e anseia por tornarse "normal". Ele arranja trabalho em uma serralheria e lá conhece Vickie com quem inicia um relacionamento amoroso. Ela e Carlos, cunhado de Walter, são as únicas pessoas com quem ele mantém algum vínculo. Ironicamente o único apartamento que ele consegue alugar, em função de ser um ex-detento, tem como vista o playground de uma escola. E ao observar a movimentação das crianças na entrada da escola, ele descobre um outro homem (Candy) que também as observa e no qual reconhece a intenção pedófila. Freqüentemente visitado e vigiado por um policial, Lucas, que não acredita na possibilidade de recuperação desse tipo de "doentes", Walter questiona-se se deve ou não denunciar o outro homem. Seu dilema também se revela nos encontros com o psiquiatra, realizados em função de sua condicional, a quem revela o desejo de ser "normal". Apesar de tentar controlar seus impulsos, Walter acaba se aproximando de Robin, uma garotinha de onze anos. Contudo, no derradeiro momento, instantes antes de concretizar seu desejo, ele descobre que Robin era molestada pelo próprio pai, visivelmente perturbado pela revelação, ele a manda embora. Depois disso, ao se deparar com Candy em companhia de um garotinho, Walter é tomado pela fúria e o espanca até deixá-lo inconsciente. Seu ato é reconhecido por Lucas que Ihe dá finalmente um voto de confiança. Após tudo isso, Walter aceita ir morar com Vickie e consegue o desejado encontro com a irmã, o qual, no entanto, não parecer ser muito bom. 


\title{
Chapeuzinho vermelho: uma parábola sexual
}

\author{
"As crianças sabem de algo que não podem explicar; \\ gostam de Chapeuzinho vermelho e o lobo na cama." \\ Djuna Barnes
}

Uma menina, um lobo, um encontro na floresta... A estória de Chapeuzinho Vermelho é talvez um dos mais conhecidos de todos os contos de fadas. Dentre suas muitas versões as mais famosas são: a de Charles Perrault (1697), primeira versão publicada da estória, e a dos Irmãos Grimm (1812), que se tornou a mais popular.

No livro O Grande massacre de gatos e outros episódios da história cultural francesa, Robert Darnton apresenta uma versão camponesa da estória, $A$ história da avó, que se acredita ter sido uma das fontes de Perrault. Nesta versão, o Lobo não devora a avó, mas após matá-la coloca o sangue em uma garrafa e corta a carne em fatias, oferecendo depois este banquete à menina, tal cena é observada por um gato que comenta: "Menina perdida! Comer a carne e beber o sangue de sua avó!". O lobo (disfarçado de avó) manda a garota despir-se e deitar-se na cama com ele. Ao ir tirando as peças de roupa, a menina vai perguntando onde deve colocá-las, recebendo sempre a mesma resposta: "Jogue no fogo. Você não vai precisar mais dela". Ao deitar-se na cama a menina começa a percebe as discrepâncias entre o corpo do lobo e o que deveria ser o corpo da avó. Até o momento em que se dá conta dos dentes tão grandes do lobo-avó, que conforme ele diz a garota, são para comê-la melhor. E dizendo isso ele a devora. Conforme explica Darnton, essas narrativas populares na verdade não eram especificamente destinadas às crianças, nem muito menos se prestavam a fins pedagógicos.

É na versão de Perrault, dedicada às crianças, que a narrativa ganha concepções pedagógicas, uma vez que para o escritor a essência do livro infantil deveria ser a moralidade cristã transmitida de maneira sutil para ser eficaz. Assim como na versão camponesa, em sua estória não há o resgate da menina e de sua avó. O resgate surge na versão dos irmãos Grimm e é incorporado pelas versões subseqüentes. A estória de Perrault termina com um pequeno poema, não existente nas outras versões, que dá ao leitor a "moral" da estória a ser guardada:

Vimos que os jovens,

Principalmente as moças,

Lindas, elegantes e educadas,

Fazem muito mal em escutar

Qualquer tipo de gente.

Assim, não será de estranhar

Que, por isso, o lobo as devore.

Eu digo o lobo porque todos os lobos

Não são do mesmo tipo.

Existe um que é manhoso

Macio, sem fel, sem furor. 
Fazendo-se de íntimo, gentil e adulador,

Persegue as jovens moças

Até em suas casas e seus aposentos.

Atenção, porém!

As que não sabem

Que esses lobos melosos

De todos eles são os mais perigosos. (PERRAULT, 1987: 23)

Fica evidente a censura de Perrault ao comportamento mais extrovertido e "ousado" das meninas, que, principalmente as "Lindas, elegantes e educadas", ao conversarem com estranhos (qualquer tipo de gente) colocam-se à mercê de serem "devoradas". O conto pretende então alertar as jovens virgens (da França do século XVII) a tomarem cuidado com os "lobos", principalmente os gentis, pois estes são os mais perigosos, capazes de segui-las pelas ruas e chegar até dentro de suas casas.

Foi Perrault quem vestiu a menina com o famoso capuz vermelho e a batizou de Chapeuzinho Vermelho, que passou a ser então o título da estória. E ao escolher a cor vermelha que remete ao sangue, à menstruação, à libido e ao coração, e que à sua época era a cor das prostitutas e do escândalo, Perrault representa ao mesmo tempo o pecado da menina e o seu fatídico destino. A cor vermelha do chapéu enquanto símbolo do sangue menstrual estaria então diretamente associada à transição da infância para a vida adulta, à passagem de menina à mulher. A conotação sexual do conto se revela ainda na expressão popular à época de Perrault: elle avoit vû le loup (ela viu o lobo), utilizada como sinônimo para a perda da virgindade.

A versão dos Irmãos Grimm mantém o chapéu vermelho, mas agora ele é de veludo e pequeno à maneira das mulheres da aristocracia e da classe média à época. Para Erich Fromm: "O 'chapeuzinho vermelho de veludo' é um símbolo da menstruação. A menina de cujas aventuras nos falam tornou-se adulta e vê-se agora defrontada com o problema do sexo." (FROMM, 1973, p. 175) E, segundo Bruno Bettelheim:

Em "Chapeuzinho Vermelho", tanto no título como no nome da menina, enfatiza-se a cor vermelha, que ela usa declaradamente. O vermelho é a cor que significa as emoções violentas, incluindo as sexuais. O capuz de veludo vermelho que a avó dá para Chapeuzinho pode então ser encarado como o símbolo de uma transferência prematura da atração sexual (BETTELHEIM, 2004, p. 209).

Desta forma, usar o chapeuzinho vermelho representa o desabrochar sexual da menina que, contudo, é ainda incapaz de lidar com essa sexualidade e com o que ela atrai. E tanto para Fromm quanto Bettelheim o conto é uma espécie de "parábola sexual". Para Bettelheim a estória de Chapeuzinho atrai as crianças inconscientemente justamente por corporificar a combinação de emoções opostas que caracteriza o conhecimento sexual infantil. Tais implicações sexuais permanecem pré-conscientes e assim trabalham a ansiedade e a excitação da criança em relação à idéia do ato sexual.

A famosa ilustração de Gustave Doré para o episódio do Lobo e Chapeuzinho na cama apresenta um Lobo de expressão serena vestindo as roupas da avó enquanto 
Chapeuzinho, tentando cobrir-se com o lençol, lança um olhar intrigado para o loboavó deitado a seu lado, parecendo dividida por sentimentos ambivalentes de atração e repulsa. ${ }^{7}$ Conforme Bettelheim, essa combinação de sentimentos pode ser descrita como fascinação:

[...] a mesma fascinação que o sexo, e tudo o que ele envolve, exerce sobre a mente da criança. É esta fascinação "mortal" com o sexo - que é experimentada simultaneamente com grande excitação e grande ansiedade - que está ligada aos anseios edípicos da menina pequena pelo pai, e com a reativação dos mesmos sentimentos de forma diferente durante a puberdade. Sempre que estas emoções reaparecem, evocam as lembranças das inclinações da menina pequena para seduzir o pai, e outras memórias de seu desejo de ser seduzida por ele, também (BETTELHEIM, 1980, p. 212).

Desta forma, é a persistência no inconsciente das ligações edípicas que pode fazer com que a menina se exponha perigosamente a possíveis seduções, representadas no conto pela ameaça de Chapeuzinho ser "devorada". A estória representa então a dualidade de emoções, atração e repulsa, que se associa ao conhecimento da sexualidade por parte da criança.

No livro Fadas no divã, Diana e Mario Corso descrevem de forma bem clara a maneira como o conto trata da curiosidade das crianças em relação à descoberta das demandas sexuais:

\begin{abstract}
Chapeuzinho é uma menina com ingenuidade de quem não sabe - e ainda não suporta saber - sobre o sexo, mas sua intuição lhe diz que há algo a mais que anima os seres vivos. Embora ela leve doces para a vovozinha, parecendo que na vida comer é a maior satisfação e a solução para todos os males [...], ela encontra no caminho outros encantos: a lábia lupina, as flores, as borboletas e o prazer de brincar. Ela representa a transição da aparente inocência infantil para o conhecimento da existência das práticas sexuais adultas, que surgem na vida da criança às vezes através de uma sedução imaginada ou, em casos graves e traumáticos, vivida (CORSO, 2006, p. 53).
\end{abstract}

Através da estória, a criança pode então lidar de maneira simbólica com essa transição da ignorância para o conhecimento sexual, vivenciando os perigos do conflito edípico e sendo salva deles, e, com isso, pode amadurecer livre de conflitos. Mas também o adulto é atraído pela narrativa da estória através da qual ele pode lembrar "vagamente" de sua própria fascinação infantil em relação ao sexo. Uma vez que todos nós já fomos um dia, tal Chapeuzinho Vermelho, curiosos por investigar qual nosso papel nas demandas sexuais recém descobertas.

\footnotetext{
${ }^{7}$ Bettelheim utiliza justamente essa ilustração na capa de seu livro $A$ psicanálise nos contos de fadas, mas ele faz uma alteração na imagem branco e preto inserindo uma marca de rubor na face da menina.
} 


\title{
O lenhador e Chapeuzinho vermelho: diálogos possíveis
}

\author{
"Você acredita em contos de fada?" \\ Lucas em O lenhador
}

A memória da estória de Chapeuzinho Vermelho (quem não a conhece?) permeia a $O$ lenhador em um jogo que se depreende da relação entre o enredo do filme e o enredo do conto. Desta forma, a análise comparatista das confluências, bem como das diferenças entre as narrativas instaura vários níveis de leitura e de interrelações, que as resignificam. O dialoga existente entre $O$ lenhador e Chapeuzinho Vermelho é evidenciado em um dos encontros entre Walter e Lucas, quando o policial conta a história de um homem condenado à morte por violentar e assassinar uma menina. Ele relata como o homem coagiu a menina a acompanhá-lo e como alguns dias depois o corpo mutilado da garota foi encontrado. Subitamente, porém, ele interrompe sua narrativa para pergunta se Walter acredita em "contos de fadas". Walter responde que não, o policial concorda com ele, mas segue perguntando: What's the one with the woodsman?

\author{
WALTER \\ Woodsman? \\ LUCAS \\ The one with the ax? \\ WALTER \\ I don't know. \\ LUCAS \\ Sure you do. He cuts open the wolf's stomach, and the girl steps out alive. \\ WALTER \\ Little Red Riding Hood. \\ LUCAS \\ That's it. Little Red Riding Hood jumps out of the wolf's guts with hardly a scratch. \\ Ever see a seven-year-old girl sodomized almost in half? She looked so small and \\ broken. I saw hardened twenty-year veterans cry. They cried like babies. I was \\ there. Ain't no fucking woodsman in this world. (FECHTER; KASSEL, 2002)
}

A estória de Chapeuzinho Vermelho e a história do assassinato da garotinha se imbricam na fala de Lucas e os limites entre uma e outra são abolidos. Através da discussão acerca do conto o título do filme é ressignificado e a estória de Chapeuzinho é revelada como intertexto em constante diálogo com a narrativa fílmica. Contudo, apesar da confluência de episódios e de signos narrativos que revelam a intertextualidade entre as obras, é na diferença que o filme se revela. Enquanto no conto infantil a questão principal é a experiência vivida por Chapeuzinho Vermelho, a perda da inocência em sua relação com o Lobo, sendo salva ou não da barriga da fera; no filme, ao contrário, é a experiência de Walter (lobo e lenhador) que está no centro da narrativa. Desta forma, o filme inverte a estrutura do conto ao colocar como protagonista o lenhador que no conto, apesar de ser um personagem decisivo, é secundário. Ao falar do conto, Lucas se remete primeiro à figura do lenhador e não à figura da garotinha (Chapeuzinho Vermelho), revelando assim a sua leitura da narrativa centrada na figura do adulto que deveria proteger e salvar a criança. 
Na versão de Perrault, o Lenhador aparece apenas de relance no episódio do encontro entre Chapeuzinho Vermelho e o Lobo na floresta, mas de forma fundamental à trama, pois é sua presença que impede o animal de devorar a menina ali, adiando o desfecho fatídico para o interior da casa da avó, local em que, contudo, não haverá um salvador. Já na versão dos irmãos Grimm após a avó e Chapeuzinho serem devoradas aparece o caçador que, abrindo a barriga do Lobo ainda vivo, retira as duas sãs e salvas do interior das entranhas do animal em uma espécie de cesariana, enchendo a barriga do animal com pedras. ${ }^{8}$ Em outras versões posteriores a figura do lenhador substituirá a do caçador, como na versão de Georgie Adams (1996). ${ }^{9}$

No filme, Lucas assume a posição de narrador, mas se sua narrativa inicia aproximando-se à versão dos irmãos Grimm, pois ele refere o resgate de Chapeuzinho do interior da barriga do Lobo, ao final é mais condizente com a versão de Perault, pois em sua narrativa a garotinha não foi salva. Mas a moral da estória desvelada aos seus ouvintes, Walter e nós espectadores, é de que no mundo real não existe "lenhador". Através da narrativa de Lucas se evidencia então a confluência entre as narrativas, evidenciando a figura do Lobo enquanto representação do molestador.

Como se vê a versão contada por Lucas nasce do imbricamento entre as várias versões que com o passar do tempo vão sendo apropriadas e transformadas no jogo entre memória e esquecimento que configura o processo de leitura e de reescritura. Essa transformação revela a experiência que todos nós já vivenciamos de recontar uma estória infantil, provavelmente escutada muitas vezes em nossa infância, inserindo ou omitindo algum detalhe, resgatando assim a tradição oral original em que contar a estória era também reinventá-la. Conforme Bettelheim:

o conto de fadas folclórico [...] resulta de ter sido moldado e remoldado por milhões de narrativas feitas por diferentes adultos para todos os tipos de outros adultos e crianças. Cada narrador, à medida em que a contava estória, introduzia e acrescentava elementos que a tornavam mais significativa para ele próprio e para os ouvintes, a quem conhecia bem. [...] Narradores sucessivos adaptaram a estória de acordo com as perguntas da criança, com o prazer e medo que elas expressavam abertamente ou indicavam. (BETTELHEIM, 1980, p. 185)

Desta forma, o conto recontado dentro do filme é a leitura/re-escritura realizada pelo autor/roteirista das várias versões da estória, dando ênfase justamente às preocupações e aos temores do narrador: a menina inocente atacada por um "predador" e salva por um lenhador. Essa recriação da narrativa se dá então do entrecruzamento não apenas das duas versões clássicas da estória, mas também das tantas outras versões, apropriações, citações e adaptações, não apenas literárias (desenhos animados, filmes, etc.), que coexistem no imaginário do autor. Surge assim uma outra versão contada pelo policial na qual o "lenhador" da versão de Perrault substitui o "caçador" da versão dos Grimm no resgate de Chapeuzinho do interior da barriga do Lobo, havendo uma transformação em relação às versões mais conhecidas da estória.

\footnotetext{
${ }^{8}$ Essa versão remete ao mito de Cronos, que devorou os próprios filhos, os quais depois saíram de sua barriga, colocando em seus lugares montes de pedras.

${ }^{9} \mathrm{Na}$ versão de Adams ocorrem outras alterações como, por exemplo, o fato de Chapeuzinho não ser devorada, conseguindo fugir do lobo e pedir socorro ao lenhador que retira a avó do interior da barriga do animal.
} 
A memória da estória infantil se manifesta também através da presença no filme do principal símbolo do conto; o casaco vermelho de capuz carregado por Robin, que evoca o chapeuzinho vermelho. A cor vermelha do casaco e da bola infantil que atormenta Walter em alucinações é destaca em contraste aos tons sombrios da película. Uma vez que a mise-en-scène do filme enfatiza os tons frios em nuances de cinzas e azuis reforçados pelo clima chuvoso das ruas cinzentas da Filadélfia que em combinação com os interiores ásperos dão forma e cor à severa auto-repressão de Walter. Assim como na estória infantil o vermelho representa a tensão sexual presente à narrativa. Seja através do casaco de Robin que, assim como o de Chapeuzinho, indica o desabrochar da sexualidade da menina, ou, da bola vermelha que anuncia o desejo reprimido de Walter. Primeiro no playground vazio quando a bola misteriosa vem rolando, insinuando a presença de crianças. E depois em seu apartamento quando novamente a bola surge do nada, mas desta vez seguida por uma garotinha que após apanhá-la entra no quarto e desaparece. Essa brincadeira com a bola vermelha nos remete novamente à Lolita, em uma cena breve, mas fundamental, em que Humbert observa Lolita de biquíni "vermelho" brincar com um cão e uma bola vermelha, e descobre que outro homem, Clare Quilty, também a está observando. A brincadeira é vista por Humbert como um jogo de sedução de Lolita perante o desconhecido. Também para Walter a brincadeira com a bola vermelha é um chamado de seu desejo latente e aprisionado.

Outro aspecto marcante da confluência entre as narrativas é a escolha do local para os encontros entre Walter e Robin, o interior de um parque, reconfiguração contemporânea da floresta da estória infantil. Tais encontros, releituras dos encontros entre Chapeuzinho e o Lobo, são, com certeza, os momentos mais tensos do filme.

No percurso cotidiano realizado de ônibus rumo ao trabalho Walter descobre Robin e passa a observá-la até o dia em que sucumbe ao desejo e a segue ao interior de um parque. $\mathrm{E}$, assim como o Lobo, é no interior do parque, local isolado, que ele a aborda. Walter é cordial e sedutor, e Robin, tal Chapeuzinho, é receptiva e condescendente.

Na versão dos Irmãos Grimm, o Lobo desvia a atenção da garota que deveria manter-se no caminho rumo à casa da avó: "Veja como são lindas as flores ao seu redor. Por que não dá uma olhada? Acho que nunca parou para escutar o canto dos pássaros... aqui na floresta tudo é prazer e você está caminhando atenta como quando vai à escola." (GRIMM, 2002, p. 32) No filme, a primeira abordagem de Walter à Robin ocorre justamente quando ela está observando pássaros, ele se aproxima e inicia uma conversa simpática e trivial, mostrando-se interessado no que ela está fazendo. Mas quando ela lhe pergunta se ele também é um observador de pássaros, ele responde: "Me? Nah. I'm more of a people watcher." (FECHTER; KASSEL, 2002)

Assim como no conto infantil é através do diálogo, através do discurso sedutor, que Walter se aproxima e envolve Robin. Lembremos que a palavra seduzir tem sua origem em seducere, palavra latina que significa "levar para o lado", "apartar", ou seja, fazer com que se desvie do caminho certo, ou principal. ${ }^{10}$ Tanto o Lobo quanto

\footnotetext{
${ }^{10}$ Entre as acepções dicionarizadas de "sedução" destacamos: inclinar artificiosamente para o mal ou para o erro, desencaminhar; enganar ardilosamente; desonrar, recorrer a promessas, amavios ou encantos; atrair, encantar, deslumbrar. (AURÉLIO, 1976).
} 
Walter dissimulam suas reais intenções, mas através de uma aparente conversa casual os seus verdadeiros desejos são gradativamente revelados, ao tom amistoso de suas falas subjaz um jogo de dominação e sedução.

Como podemos constatar, o ponto forte de intertextualidade entre o filme e o conto infantil se constrói na interação entre as personagens: Walter e Robin, que recria a relação entre: o Lobo e Chapeuzinho.

\title{
Lobo em pele de cordeiro
}

\author{
"O caçador pegou a pele do lobo." \\ Chapeuzinho vermelho, Irmãos Grimm
}

A identificação de Walter como o "lenhador" que dá título ao filme é inferida logo no início da narrativa quando ele vai trabalhar em uma madeireira e será reforçada posteriormente com o desvelamento da intertextualidade entre o filme e o conto.

Além disso, a instância narrativa do filme é dominada pela focalização em Walter tanto no âmbito audiovisual, os espectadores vêem e ouvem aquilo que ele vê e ouve; quanto no mental, construída através do artifício da voiceover, que permite aos espectadores conhecerem os pensamentos do protagonista. Uma exceção significativa é o episódio final quando a instância narrativa centra-se em Vickie que à distância observa o encontro entre Walter e a irmã, e nós espectadores então, assim como ela, assistimos de longe sem nada escutar.

Em decorrência destes artifícios narrativos e cinematográficos logo identificamos como questão principal do filme o drama vivido por Walter - protagonista e foco narrativo. O sucesso do filme depende então em grande parte da performance de Kevin Bacon: seu olhar, apesar de atento, desolado; sua boca tensa e seus movimentos inquietos, mas retesados revelam a agonia interior do personagem. Nos encontros entre Walter e Robin, o talento do ator se revela, pois ele consegue demonstrar as nuances da transformação do personagem: de um Walter taciturno e desconfiado Bacon faz surgir um Walter simpático e caloroso que sorri com genuíno prazer: seus olhos se abrem, ele se solta e seu corpo relaxa. Adentrando o universo da menina, ele não está apenas excitado, mas se mostra realmente feliz e extremamente à vontade, revelando uma outra identidade. Contudo, sua amabilidade para com Robin, nos permite reconhecer como seu crime, execrável que é aos nossos olhos, se utiliza de um real prazer no mundo das garotinhas e de como elas por sua vez são levadas a confiar nele e a desejar sua companhia. Nestes encontros cruciais, a atuação de Bacon é comovente, combinando com maestria pathos e medo, ele consegue transmitir ao espectador a alegria de Walter em estar junto à garotinha e a ânsia que sente por saciar seu desejo, mas também sua angústia quando tem consciência do dano que isso causaria à menina.

É através desta dualidade de sentimentos, configurada na luta por controlar seu impulso pedófilo, que se constrói a figura de Walter. Sua identidade é no mínimo dupla, sendo ao mesmo tempo predador (lobo) e salvador (lenhador). Esta ambigüidade da instância masculina remete à versão dos irmãos Grimm, na qual, conforme aponta Bettelheim, a imagem do macho se divide em duas figuras opostas: 
"a do sedutor perigoso que, se cedermos a ele, se transforma no destruidor da avó e da menina; e a do caçador, a figura paterna responsável, forte e protetora." (BETTELHEIM, 1980, p. 208) E mesmo que em Chapeuzinho Vermelho nunca se faça referência ao pai da menina, a figura paterna é representada através destes dois personagens: "como o lobo, que é uma externalização dos perigos de sentimentos edipianos reprimidos, e como o caçador na sua função resgatadora e protetora." (BETTELHEIM, 1980, p. 214) Também em O lenhador a figura paterna não é central na narrativa, mas está presente: o pai de Robin, que é apenas referido, e o cunhado de Walter, cuja relação com a filha instiga a curiosidade do protagonista que chega a questioná-lo quanto aos sentimentos por ela. Desta forma, a figura paterna, ou melhor, a condição edípica paira sobre a narrativa, culminando quando Walter se identifica com o pai de Robin, momento de reconhecimento em que ele confronta a imagem paterna que enquanto deveria proteger, acaba por molestar. Em Lolita, o conflito edípico é ainda mais explícito, uma vez que Humbert ao casar-se com a mãe da menina acaba se passando por seu pai, sendo, em verdade, o único pai que ela conheceu.

Segundo Bettlheim a figura do caçador é identificada à figura paterna que deve proteger a menina, sendo o personagem mais atraente do conto, tanto para os meninos quanto para as meninas, pois é quem salva os bons e castiga o malvado. Contudo, se não existisse em nós uma parte que aprecia o lobo, ele não teria poder algum sobre nós.

Assim como no conto, onde tanto o lobo quanto o lenhador são a representação da figura paterna velada, no filme, estas duas instâncias são incorporadas por Walter, mesmo que a princípio a natureza de lobo fale mais alto que a de lenhador. A dicotomia entre as duas instâncias é igualmente reconstruída nas relações entre os personagens masculinos: Lucas - o policial (lenhador que observa Walter) e Walter (lobo que é observado pelo policial); Walter (lenhador que observa e puni Candy) e Candy (lobo que é observado e punido por Walter).

Observando de sua janela a chegada das crianças à escola, Walter percebe que há um outro homem que também as observa. Ele passa então a registrar em um diário tudo o que vê e pensa em relação a este outro homem, a quem ele denomina de Candy (Doce) em uma clara alusão ao ato de oferecer doces às crianças para atraí-las. Contudo, há também um tom sarcástico, ao dar um nome "doce" para uma figura abominável. Através do recurso da voiceover, nós espectadores escutamos o que Walter escreve, descrevendo e comentando o que vê. Ele oscila entre dois sentimentos: recriminar a ação de Candy e chamar a policia, ou considerar as crianças capazes de escolher em ceder ou não ao assédio. Mas esse confronto de sentimentos dá lugar a um discurso sarcástico quando Walter descreve como um narrador esportivo a cena da investida de Candy ao menino (o querubim) como se fosse uma luta de boxe:

Good morning, fellow sports fans. The match is about to begin. Candy enters the arena looking sweet and trim. He checks out the scene but plays it cool. He's definitely holding back. (pausa) Uh-oh, Candy's eyes have locked onto something. Oh yeah. A cherub of a lad has separated from his friends. Candy quickly makes his move. He pats the cherub on his head, ruffles his hair. With his other hand, he offers the boy a bag of M\&Ms. Jumbo size. Round one to Candy. (Candy points 
across the street to his white Volvo.) A very risky move by Candy. The boy looks at the car but walks away! (Candy follows the boy. Freeze frame.) Round two goes to the cherub. I have never seen Candy act so cocky. The cherub looks at Candy; the cherub looks at the car; the cherub looks for his friends. But his friends are long gone. The cherub is alone. The cherub crosses the street! (Candy opens the car door.) The cherub gets in the car. (FECHTER; KASSEL, 2002)

Este episódio é anterior à cena da primeira investida de Walter à Robin. Ou seja, ele próprio está em um espaço nebuloso onde os limites entre certo e errado são indefinidos, incapaz que é de compreender o quão danoso seus atos foram, uma vez que tem certeza de jamais haver "ferido" alguma das garotinhas. A figura de Candy funciona então como um duplo, espécie de reflexo no qual Walter não quer se reconhecer e com o qual se confronta, primeiro interior e psicologicamente e, finalmente, de forma física. E o sarcasmo de seus pensamentos parece ser uma forma de distanciar-se da situação. Por outro viés, seu monólogo irônico o aproxima da figura de Humbert, narrador-protagonista de Lolita, que igualmente possui um duplo, Clare Quilty, ao qual denomina de "meu irmão" e que termina por enfrentar e assassinar, crime que o leva à prisão. Assim como Walter e Candy, Humbert e Clare Quilty não são representados em um binarismo maniqueísta, pelo contrário, eles são muito simétricos e um aspecto em especial os aproxima ambos são literatos. Aliás, Humbert parece tentar "descobrir" uma tradição de pedófilos escritores, enumerando uma lista de ilustres colegas de vício: Virgílio, Dante (que se apaixonou por Beatriz quando ela tinha nove anos) e Petrarca (que se apaixonou por Laura então com doze anos). Ele desvela essa tradição parecendo desejar ser posteriormente ele próprio inserido ao clube. Uma vez que, segundo ele, é preciso ser "um artista e um louco, uma criatura de infinita melancolia, com um borbulhar de veneno ardente no lombo e uma chama supervoluptuosa a arder permanentemente na delicada espinha" (NABOKOV, 1981, p. 22) para discernir e assim reconhecer "o fatal diabrete" entre as demais meninas. Assim, Humbert revela sua própria condição enquanto escritor. Sua narrativa vai citando e aludindo aos seus parceiros escritores e pedófilos, e sua relação mais intensa parece ser com Edgar Allan Poe: "Virginia não tinha ainda completado catorze anos, quando Harry Edgar a possuiu. Ele dava-Ihe lições de álgebra." (NABOKOV, 1981, p. 58)

O detalhe das aulas de álgebra traz à memória outro notório escritor também envolvido com garotinhas, Lewis Carroll. Carroll era professor de matemática e com isso conquistava a confiança das famílias de seus alunos e colegas, podendo então desfrutar de momentos a sós com as garotinhas, as quais ele fotografava com total liberdade, como Alice Liddell, cujo nome utilizou para batizar o seu mais famoso personagem e dar título ao livro, Alice no país das Maravilhas (1865). Além de fotografar suas amiguinhas, ele as levava ao teatro, as convidava para jantares e thes dedicava carinhosas cartas; apreciando ainda oferecer-lhes o colo e tê-las como companhia para passeios de mãos dadas. A idéia da memória de Carroll na escritura de Lolita é corroborada pelo fato de haver Nabokov traduzido Alice no país das Maravilhas para o russo e, como veremos, fazer alusão ao texto em seu romance. E em um jogo circular de referências que se entrecruzam de um texto a outro, de uma linguagem a outra, também em $O$ lenhador, a estória infantil criada por Carroll é referida. Quando Lucas pergunta sobre a crença de Walter em "contos de fadas", ele dá como exemplo Alice no país das maravilhas. A menção ao texto de Carroll, apesar 
de breve, abre mais uma vereda intertextual para o filme, que nos remete a reconhecermos no episódio da alucinação de Walter o mesmo clima onírico das fotografias de Carroll.

Vale lembrar que nas últimas páginas de Alice no país das maravilhas o Coelho Branco, cujo parentesco com o Lobo não é longínquo, saí em defesa da menina, lendo um poema que termina assim:

Não deixes ver que ela os tem amado.

Deve ser isso, para sempre, pois,

Um segredo, aos demais ocultado,

Somente entre nós dois. (CARROLL, p. 149)

Não fica difícil lermos nestes versos a declaração de amor do Coelho Branco à Alice, mas de um amor que deve ser mantido em segredo. Lobo, Coelho Branco, Humbert, Walter, todos parecem compartilhar uma mesma essência, o desejo e o prazer na companhia de garotinhas, cada um a seu modo.

Através de Lolita articulam-se vários entrecruzamentos literários que reverberam no filme de Kassel. Além de fazer referências às biografias de escritores para sinalizar inter-relações literárias, Nabokov constrói uma rede intertextual, colocando os textos em constante diálogo. Não é mero acaso o primeiro e inesquecível amor de Humbert (morta pelo tifo ainda na infância) chamar-se Annabel Leigh, como a musa que dá nome ao poema "Annabel Lee" de Poe:

\footnotetext{
It was many and many a year ago,

In a kingdom by the sea,

That a maiden there lived whom you may know

By the name of Annabel Lee;

And this maiden she lived with no other thought

Than to love and be loved by me.

I was a child and she was a child,

In this kingdom by the sea; (POE, 1849)
}

O texto de Nabokov dialoga com o poema de Poe, ao recriar a história de amor descrita pelo poeta: na praia duas crianças descobrem o amor, mas a menina morre, eternizando a lembrança melancólica desse amor perfeito. Nabokov constrói através da nostalgia deste amor infantil, da lembrança da Annabel que Humbert "reconhece" em Lolita, o cerne do desejo pedófilo de Humbert: "de uma maneira mágica e fatal, Lolita começou com Annabel." (NABOKOV, 1981, p. 17) Walter igualmente possui um "original" perdido na infância, a lembrança do prazer de cheirar os cabelos da irmã, Annette. Ambos parecem prisioneiros dos jogos sexuais da infância e sem conseguir esquecê-los permanecem na busca de um amor primordial desaparecido. Adultos, eles encontram nas meninas a reprodução da fatídica paixão original e empenham-se nos jogos por seduzi-las.

Contudo, enquanto Humbert não quer a remissão de seus pecados, mas anseia por perder-se no paraíso proibido de seu desejo ardente por estas sedutoras diabretes, que ele batizou de ninfetas. Walter parece tentar purgar sua culpa ao surrar Candy, revelando assim sua porção lenhador (caçador). 


\title{
Sobre meninas e lobos
}

"Vou contar-Ihes algo muito estranho: foi ela quem me seduziu."

Lolita, Wladimir Nabokov

A transposição de Chapeuzinho dos contos de fadas para o filme de Kassel, reconfigurada na figura de Robin, repete a condição frágil e a aparente passividade da menina da estória infantil. Robin é interpretada por Hannah Pilkes que corporificar com sutileza a reticência e a aflição do personagem: uma menina tímida e introspectiva que em nada lembra a imagem da ninfeta descrita por Nabokov:

\begin{abstract}
Entre um limite de idade que vai dos nove aos catorze anos, existem raparigas que, diante de certos viajantes enfeitiçados, revelam sua verdadeira natureza, que não é humana, mas "nínfica" (isto é, demoníaca), e a essas dadas criaturas proponho designar como nymphets. [...] São todas as meninas, entre esses limites idade, nymphets? Claro que não. [...] Tampouco a beleza serve para formar qualquer juízo a respeito; e a vulgaridade, ou pelo menos o que determinada comunidade assim o classifica, não confere, necessariamente, certas características misteriosas, a graça tresloucada, o charme indefinível, astuto, insidioso, que despedaça almas e que distingue a nymphet de certas de suas coevas. (NABOKOV, 1981, p. 21)
\end{abstract}

Apesar de estar dentro da faixa etária definida por Humbert, Robin não apresenta os encantos nínficos que se revelam através do comportamento das garotinhas "saidinhas", cujas ações, como aponta o narrador, podem ser vistas por alguns como vulgares. Chapeuzinho Vermelho, Alice e Lolita são vivazes, a última chega mesmo a ser esfuziante, já Robin é apática e vitimizada.

A imagem da ninfeta urdida por Nabokov parece aludir à imagem das garotinhas fotografadas por Carroll, cujo detalhe ou o punctun (como denomina Barthes) nínfico é desvelado pela lente do fotógrafo no inocente entrever do corpo pueril, um ombro ou uma perna à mostra, "algo mais" do que seria apropriado mostrar à época vitoriana $A$ presença da Alice de Carroll como uma das memórias entretecidas na configuração da Lolita de Nabokov é clara: "o alerta periscópio de meu vergonhoso vício, distinguia de longe a nymphet meio despida, imobilizada no ato de pentear os cabelos de Alice no País das Maravilhas." (NABOKOV, 1981: 360-1) A idéia da imagem "imobilizada no ato" remete à ação fotográfica de Carroll que retratava as garotinhas em situações cotidianas como a de pentear o cabelo. Mas ele também as fotografou como personagens e não é surpreendente que uma de suas obras, intitulada "Chapeuzinho Vermelho", apresente uma garotinha vestida como tal. O que chama atenção em todas as suas fotos é que as garotinhas estão à vontade, não parecem acanhadas ou enfadadas pelo ato fotográfico, mas sim entregues a uma agradável brincadeira. Esta atmosfera onírica de suas fotografias parece ter sido resgatada na alucinação de Walter com a garotinha e a bola.

A atitude das meninas frente ao interesse de Carroll parece originar-se do mesmo prazer experimentado por Lolita e por Robin com a atenção e o interesse que inspiram em um homem adulto. Assim, não podemos desprezar a curiosidade infantil frente às demandas sexuais, nem perpetuar a idéia de uma assexualidade infantil. 
Uma vez que, conforme as premissas freudianas, todas as atividades infantis de busca por prazer são ao mesmo tempo: sexuais e normais. Mas, por outro lado, não podemos subestimar o lobo, capaz de farejar a ninfeta, capaz de identificar a vulnerabilidade curiosa.

E assim como a ingenuidade de Chapeuzinho, que explica ao Lobo como chegar à casa da avó, é questionável, o espectador não vê na atitude de Robin, que "dá confiança" a um estranho, Walter, um ato de pura inocência. Lembremos que a estória infantil adverte quanto aos riscos a que a menina está exposta por sua ingenuidade e ignorância aos perigos, mas também aponta o quanto a sua curiosidade e os seus desejos eróticos podem levá-la a se expor. Conforme Corso: "A menina pode não saber que jogo está jogando, mas é inegável seu interesse em participar." (CORSO, 2006, p. 54) O desejo em participar deste jogo, mesmo "ignorando" o que realmente está em jogo, é evidente em Robin.

Na versão de Perrault, Chapeuzinho desconfia da voz grossa do lobo-avó, na versão dos Irmãos Grimm, ela sente um medo inexplicável de ir à casa da avó naquele dia: "Puxa! Sempre me sinto tão alegre quando estou na casa da vovó, mas hoje me sinto muito aflita." (GRIMM, 2002, p. 33) Contudo, tais desconfianças e "intuições" não a fazem recuar, pelo contrário, ela parece cada vez mais motivada a descobrir a verdade. É a sua curiosidade que constrói o famoso diálogo final com o Lobo, que, com pequenas variações, se repete em todas as versões:

- Minha avó, como você tem braços grandes!

- É pra te abraçar melhor, minha filha.

- Minha avó, como você tem pernas grandes!

- É pra correr melhor, minha menina.

- Minha avó, como você tem orelhas grandes!

- É pra te escutar melhor, minha menina.

- Minha avó, como você tem olhos grandes!

- É pra ver melhor, minha menina.

- Minha avó, como você tem dentes grandes!

- É pra te comer. (PERRAULT, 1987, p. 18-22)

Chapeuzinho controla a conversa, fazendo constatações curiosas a respeito do corpo deste lobo-avó, o Lobo apenas responde as perguntas. Mesmo assim, ela não foge, sua curiosidade a impele ao questionamento derradeiro acerca da finalidade de dentes tão grandes. Ela é uma jogadora, cujo jogo se desvela através das pistas deixadas no decorrer da narrativa, jogadora passiva, ela se deixa seduzir pelas palavras do Lobo.

Robin igualmente demonstra desconfiança ao encerrar sua primeira conversa com Walter dizendo que seu pai gosta que ela chegue antes que escureça. Decepcionado, mas cauteloso, Walter afirma que é bom para a garota escutar o que o pai diz. Contudo, a essa autêntica preocupação paterna subjaz uma outra intenção a ser desvelada. Na versão dos Irmãos Grimm, Chapeuzinho também é advertida, mas pela mãe: 


\begin{abstract}
- Trate de sair agora mesmo, antes que o sol fique quente demais, e quando estiver na floresta olhe para a frente como uma boa menina e não se desvie do caminho. Senão, pode cair e quebrar a garrafa, e não sobrará nada para a avó. E quando entrar, não se esqueça de dizer bom-dia e não fique bisbilhotando pelos cantos da casa. (GRIMM, 2002, p. 30)
\end{abstract}

Conforme Fromm, a advertência dada a Chapeuzinho é uma maneira de alertála da possível perda de sua pureza, ao desviar-se do caminho ela poderia descobrir o que há "fora da estrada" e que não deveria ser revelado. Assim, o ato de quebrar a garrafa, derramando o vinho, representaria então a perda da virgindade. No filme a advertência é corroborada pelo próprio Walter que mais uma vez apresenta uma dualidade de sentimentos: sedutor (lobo)/salvador (lenhador). Contudo, esse aviso de nada vale, pois em ambas as narrativas a menina sucumbe à lábia do sedutor. Mas Robin, assim como Chapeuzinho, não é tão ingênua quanto parece, ela reconhece a intenção de Walter e a princípio tenta escapar:

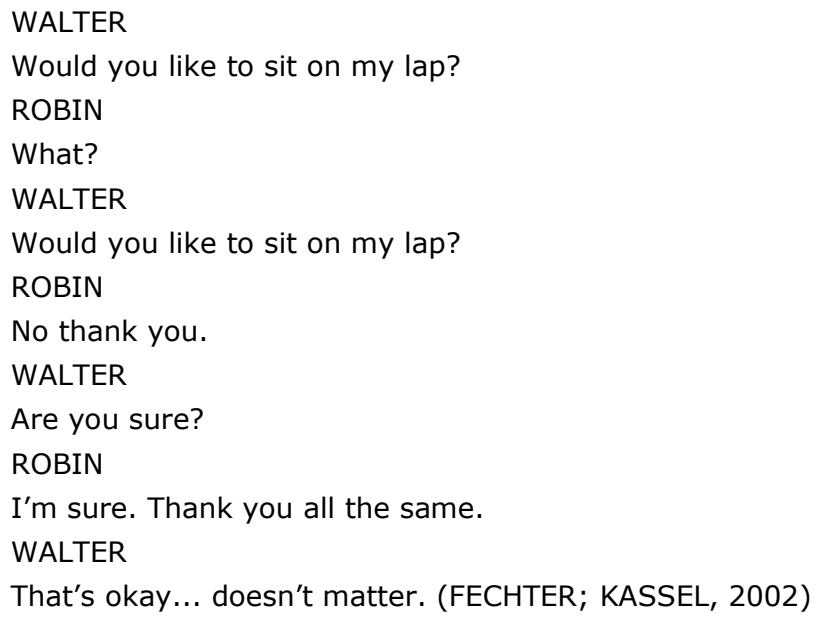

O diálogo entre eles, sentados em um banco no parque, recria a tensão do diálogo derradeiro entre Chapeuzinho e o Lobo deitados juntos na cama. Uma vez que tanto no filme quanto no conto infantil esse é o momento de revelação: do desejo pedófilo de Walter e do desejo famélico do Lobo. Mas, invertendo a lógica da estória infantil, não é a garota que descobre o perigo através das perguntas que aos poucos revelam a identidade do lobo, é Walter quem será surpreendido. Pois a garota como se tivesse medo de perder o interesse de Walter, decide ceder ao desejo do adulto e pergunta se ele quer que ela sente em seu colo; ele responde: "Yes. I would enjoy that." Ela então Ihe faz uma revelação:

ROBIN

My daddy lets me sit on his lap.

WALTER

Does he?

ROBIN 
Yes.

WALTER

Do you like it when he asks you?

ROBIN

No.

A resposta negativa de Robin tem um estranho efeito sobre Walter, que parece perder suas certezas ao confrontar a consciência de Robin da natureza nada inocente das ações do pai. O que o faz seguir questionando a garota, pois ele quer descobrir a razão dela não gostar de sentar no colo do pai:

\title{
WALTER
}

Are you two alone when he asks you?

Does he touch you?

Does he say strange things?

Does he move his legs in a funny way?

A falta de respostas de Robin que permanece em silêncio frente às perguntas de Walter vai gradativamente revelando o pai-lobo molestador. E ao reconhecer-se no comportamento deste, Walter confronta sua própria face e vê no sofrimento de Robin, decorrente dos abusos paternos, o efeito de seus próprios atos sobre as meninas que abusou. E quando Robin torna a perguntar se ele gostaria que ela sentasse em seu colo, dizendo que não se importava e que sentaria, ele responde que não e a manda ir para casa. Mas ela insiste:

\author{
ROBIN \\ Can't I stay a little longer? \\ WALTER \\ It's getting dark. Go home. \\ ROBIN \\ Will I see you again? \\ WALTER \\ Go home, Robin.
}

Assim, enquanto no conto o diálogo termina com a menina sendo devorada pelo lobo, no filme, o final do diálogo alivia a tensão criada no decorrer de toda a narrativa quanto à possibilidade de Walter reincidir em seu crime. Walter-lobo liberta a menina que estava prestes a entregar-se. Pois Robin, apesar de revelar que não gostava de fazer o que o pai pedia, se mostra disposta a fazer o mesmo com Walter. Mas apesar de Robin ser poupada de um novo abuso, ela não pôde ser salva do pai: lobo original. Assim, diferentemente do personagem dos Grimm, mas semelhante ao de Perrault, para Robin não há salvação. Desta forma, o conflito edípico identificado na estória de Chapeuzinho é evidenciado também no filme que o apresenta em diferentes níveis: de forma aberta e incestuosa entre Robin e seu pai, de forma psicológica entre Carlos e sua filha e de forma projetada entre Robin e Walter. 


\title{
E viveram felizes para sempre?
}

A memória adormecida da estória de Chapeuzinho que foi fascinante e assustadora para nossa condição infantil é despertada pelas múltiplas referências que a narrativa fílmica faz ao conto. O lenhador rearticula então para nós, espectadores adultos, o que Chapeuzinho Vermelho representou para nosso inconsciente infantil, revelando o que estava nas "entrelinhas" do conto de fadas de uma maneira não menos cruel. Para o adulto a narrativa infantil já não gera mais medo, mas no escuro do cinema o drama de Walter em sua luta para conter o "lobo" dentro de si faz com que nós espectadores prendamos o fôlego. Como se a criança, que sentia um estranho prazer com a imagem do lobo e da menina juntos na cama, espreitasse por sobre nossos ombros; convidando-nos ao desconfortável encantamento de assistir ao encontro de Robin e Walter a sós no parque. Conscientes do perigo, mas ansiosos; receosos, mas curiosos, com a mesma curiosidade que levou Chapeuzinho ao seu destino, não conseguimos fugir à última pergunta, precisamos saber a razão dos dentes tão grandes, queremos saber até onde o lobo vai.

Contudo, enquanto nos contos sempre há um final que encerra o drama da narrativa, agradável ou não, seja com Chapeuzinho sendo devorada ou sendo resgatada da barriga do animal:

\begin{abstract}
As figuras e situações dos contos de fadas também personificam e ilustram conflitos internos, mas sempre sugerem sutilmente como estes conflitos podem ser solucionados e quais os próximos passos a serem dados na direção da humanidade mais elevada. (BETTELHEIM, 1987, p. 34)
\end{abstract}

Em O Lenhador não teremos uma solução ao final da narrativa, o conflito interno vivido por Walter não foi resolvido, nem se sugere que exista uma solução. Ele passou por um momento crucial no parque com Robin ao ter de decidir em ceder ou não a seus impulsos e desejos, mas isso não pôs fim ao seu dilema. E assim também não resolve a situação do espectador, não termina com nossa ansiedade, apenas gera um alívio temporário. De forma semelhante, quando Walter castiga Candy, ele também dá a nós espectadores o que esperamos, a redenção através da violência. Mas de forma alguma podemos dizer que isso transformou Walter ou que seus impulsos pedófilos tenham desaparecido. Uma vez que seu grande drama é saber quando será "normal". Mas o que é ser normal para ele? Normal is when I can see a girl... be near a girl, even talk to a girl... and not think about... That's my idea of normal. E será que isso é possível?

Para o escorpião da fábula de Esopo que morre durante a travessia do lago por ferroar mortalmente a rã que o transportava, tudo se justifica de maneira muito clara: "Essa é a minha natureza!" Na estória infantil a questão concentra-se nas escolhas e atitudes da menina que a colocam em perigo e no aprendizado retirado dessa experiência, nunca, contudo, questiona-se a atitude do Lobo, pois essa é condizente com sua natureza carnívora. Em $O$ Lenhador, o que está em jogo é a maneira como Walter tem de conviver com a sua natureza e com as conseqüências de seus atos passados. 
Mas se o filme inova ao revelar a porção humana de um pedófilo confesso, essa humanidade, contudo, surge para justificar (ou gerar) a culpa de Walter. A princípio ele tenta controlar seus impulsos para se reintegrar à sociedade e deixar para trás o passado, principalmente os anos de detenção. Contudo, é somente ao identificar-se com o pai de Robin e compreender o sofrimento da garota, que ele tem noção do dano real causado por seus atos. Nesse momento decisivo, Walter é acometido pela culpa que o fará espancar Candy em uma espécie de purgação dos próprios pecados, mas sem alcançar a redenção. Ao final do filme a única certeza é de que Walter está lutando psicológica (o conflito entre culpa e desejo vivido por ele no parque) e fisicamente (a surra que dá em Candy) contra seus próprios demônios.

Na última cena do filme, quando Walter encontra Vickie após conversar com a irmã, ele conta que a conversa fora difícil, pois a irmã ainda estava muito magoada e brava. A namorada o consola dizendo que é uma questão de tempo e quer saber como ele se sente, questionamento ao qual ele responde indolente: I feel... okay. Walter esta tentando iniciar uma nova vida, mas a felicidade é uma terra distante em que as garotinhas podem acompanhar o Coelho Branco e na qual não existe culpa, País das Maravilhas do qual Walter está exilado.

\section{Referências}

ALTKINSON, Roland. "The Soul of a Pedophile". The Sounding Board: maio/junho 2005. Disponível em: http://www.psychflix.com/articles.html\#soul_pedophile Acessado em: 5 mai. 2005.

BETTELHEIM, Bruno. A psicanálise dos contos de fadas. Rio de Janeiro: Paz e Terra, $3^{a}$ ed., 1980.

CARROLL, Lewis. As aventuras de Alice no País das Maravilhas. São Paulo: Circulo do Livro, 1985.

VINEBERG, Steve. "Dark secret". Christian Century: 8 fev, 2005. Disponível em: http://www.findarticles.com/p/articles/mi_m1058/is_3_122/ai_n10016808 Acesso em: 19 abr. 2005.

COHEN, Morton N. Lewis Carroll: uma biografia. Rio de Janeiro: Record, 1997.

CORSO, Diana Lichtenstein; CORSO, Mario. Fadas no divã: psicanálise nas histórias infantis. Porto Alegre: Artmed, 2006.

COOPER, Rand Richards. "Unforgiven: 'The Woodsman". Commonweal: 25 fev, 2005. Disponível em:

http://www.findarticles.com/p/articles/mi_m1252/is_4_132/ai_n14925003 Acesso em: 14 out. 2006.

DARNTON, Robert. O grande massacre de gatos (e outros episódios da história cultural francesa). Rio de Janeiro: Graal, 1986.

FECHTER, Steve; KASSEL, Nicole. The Woodsman - script. 2002. Disponível em: http://www.dailyscript.com/scripts/thewoodsman.html Acesso em: 20 mar. 2007.

FROMM, Erich. A linguagem esquecida. Rio de Janeiro: Zahar, 1973. 
GRIMM, Irmãos. "Chapeuzinho Vermelho". In: TATAR, Maria (ed.). Contos de fadas. Trad. Maria Luiza X. de A. Borges. Rio de Janeiro: Jorge Zahar Editor, 2002, p. 30-36.

MORAES, Eliane Robert. "A ingenuidade de um perverso: linguagem e erotismo em Nabokov". Ide, São Paulo, n. 45, p. 115-119, dez. 2007.

NABOKOV, Vladimir. Lolita. São Paulo: Abril Cultural, 1981.

KASSEL, Nicole. "Making a monster". Evening Standard, Londres. 3 fev, 2005.

Disponível em:

http://www.findarticles.com/p/articles/mi_qn4153/is_20050203/ai_n9496530. Acesso em: 14 abr. 2005.

KEMP, Philip. "The Woodsman, Nicole Kassell's study of a convicted paedophile, lets us empathise without special pleading or sensationalism". Sight \&Sound (bfi) 2005. Disponível em: http://www.bfi.org.uk/sightandsound/review/591/Acessado em: 16 jan. 2006.

PERRAUlT, Charles. Chapeuzinho Vermelho. Porto Alegre: Kuarup, 1987.

POE, Edgar Allan. "Annabel Lee". 1849. Disponível em:

http://www.pambytes.com/poe/poems/annabel.html Acessado em: 17 set. 2005.

SANTIAGO, Silviano. "Sobre a Lolita de Nabokov \& outras ninfetas". Disponível em: http://www.pacc.ufrj.br/NABOKOV.html Acessado em: 20 de jul. 2005.

\section{Filmografia}

O Lenhador (The Woodsman). Nicole Kassell. Estados Unidos, 2005

\section{Title}

The Woodsman, a re-reading of Little Red Riding Hood

\section{Abstract}

This paper, in the tradition of comparative interdisciplinary studies, analyses the film The Woodsman as a re-reading and recreating of the fairy tale Little Red Riding Hood, analyzing the inter-textual dialogue that establishes with the two most famous versions of the children's story, by Charles Perrault and by the Grimm Brothers. The investigation of these crossovers focus on the issue of pedophilia that is openly treated in the movie and symbolically in the tales. With this purpose it is also approached the Vladimir Nabokov's novel Lolita, emblematic work in the treatment of the subject, that configures itself as a point of confluence for the narratives analyzed and it brings to the discussion another work of children's literature, Alice's Adventures in Wonderland by Lewis Carroll.

\section{Keywords}

Cinema. Literature. Fairy tales. Pedophilia.

Recebido em 18.04.2011. Aprovado em 11.07.2011. 